\title{
Tudo igual
}

Kelly Gomes Cavalcante ${ }^{1}$

Praia da Ponta Negra, Rio Negro, à noite até a areia é negra - de longe -, como o céu também. Pessoas na orla, na praia, nos bares, nas barracas, na água, nos prédios, nos barcos.

Nos noticiários a respeito da nova orla da digníssima praia da Ponta Negra foi incansável a repetição da palavra "revitalização". Pensando a respeito deste "dar nova vida", vem a curiosidade de observar o que mudou relativo à vida no local. Qual é essa nova vida? Logo veio à mente uma cena de filme, um casal bonito, com sandálias nas mãos, caminhando pela areia com seus sorrisos perfeitos e os cabelos ao vento. Mas não, aqui não "caboco". Manaus é "pai d'égua".

O que encontramos? Uma família fugindo à rotina em plena segunda-feira, mergulhando no rio, correndo na areia, um vendedor de bugigangas, algumas barracas de bebidas, pessoas bem à vontade, desarrumadas, desajeitadas, deselegantes, o rapaz com a mochila desbotada daquela marca com nome costurado em relevo nas alças, a mocinha "puro charme" com o vestido tipo sanfonado curtíssimo e coladinho ao corpo, uma garrafa de cachaça ou vodka barata, quem sabe até misturada com quisuque, um moleque pedinte solicitando um lanche, "só uma bolacha, moço, nada mais" e, com o nariz remetido ao céu, recitando poética e orgulhosamente não estar pedindo dinheiro - quando ele sabe que dificilmente alguém teria um lanche guardado estrategicamente no bolso para ocasiões como aquela -, um cidadão incomodado com o pedido, principalmente por se ver obrigado a dar-lhe dinheiro para não parecer sovino diante de sua colega aventureira.

Ademais - ouvi alguém utilizar essa palavra por esses dias, confesso que não a usaria numa situação como essa - temos de volta, portanto, pousadas sobre areia, as antigas e vívidas barracas de bebidas e outros "suprimentos", o odor de urina, que havia deixado saudade, principalmente nos muros dos banheiros que, se ainda não o sabe, são pagos e que bom que o são. Pensar no lado positivo da coisa ajuda: além de servir para manter os banheiros “utilizáveis" por mais tempo, quando cobram por seu uso não o fazem pela classificação do feito em número um ou número dois; quanto às barracas, você tem o prazer e a comodidade de comprar sua bolacha, seu pacote de salgadinho de milho, sua bebida para "encher a cara" e se enturmar com a galera despachada.

\footnotetext{
${ }^{1}$ Aluna do Curso de Mestrado em Literatura, pelo Programa de Pós-Graduação em Letras da Universidade Federal do Amazonas - UFAM. E-mail: kelly.cavalcant@gmail.com
} 
E a música? Já ia esquecendo da música. E dá para esquecer? As músicas estão ali para diversos gostos, quase que para todos os gostos e todas ao mesmo tempo, "até o toco", em toda parte, uma confusão alegre de sons na qual raramente se distingue o estilo, talvez porque se tornam uma só, um novo estilo talvez.

Dá licença de eu recitar umas músicas que eu lembrei? "Mudaram as estações, nada mudou, mas eu sei que alguma coisa aconteceu..." e tem aquela "Cada qual com seu James Brown, salve o samba, hip-hop, reggae ou carnaval, cada qual com seu Jorge Bem, salve o jazz, baião, e os toques da macumba... Tudo, tudo, tudo, tudo, tudo igual".

Só por curiosidade, pode-se dar uma paradinha para bisbilhotar aquelas "motonas" enlouquecedoras e absurdas de tão potentes, paradas em comboios no calçadão e que impressionam, se essa é a melhor palavra.

Também não dá para deixar de notar, à medida que você vai passando o olhar, que a pirâmide social local se molda ao calçadão, às escadas, à areia. $\mathrm{O}$ topo da pirâmide se torna $\mathrm{O}$ calçadão e a base a areia e o rio. Os vizinhos dos prédios se mantem com seus poodles, malteses, chihuahuas e collies em postura de sentido - tanto os donos quanto os cães - no calçadão ou correndo ou caminhando ou nas lanchonetes, nos bares caros, passeando com suas crianças em bicicletas ultramodernas, patins, skates e brinquedos motorizados, de mãos dadas os casais nas sorveterias ou provando um açaí incrementado no gosto e no preço, um sushi na hora, um tacacá com bossa, uma torta arrumada, entregando um cachê para a banda que toca no píer do bar que serve um chopp limpo e gelado. Enquanto isso, as pessoas que vem de mais longe, do mais longínquo recanto "quixitônico" ou dos céus da cidade de Deus, circulam pela areia, entram na água, sentam nas cadeiras sujas das barracas à beira da praia.

Curiosamente, é sempre o caboclo selvagem que se joga no rio sem medo e sem preconceito, rola na areia, senta onde quer, arma barraca e arma barraco, mas quer antes de tudo se divertir, pretende primeiro rir, gritar, cantar, jogar bola, sem deixar, é claro, de assistir aos policiais brincando naqueles triciclos motorizados radicais.

As luzes dos prédios e das pessoas ali em cima competem com o brilho do rio e dos olhos alegres das pessoas lá embaixo. O pôr do sol enfrentando árdua luta contra às coberturas dos prédios e o cair da noite aparado pela baixa altura da praia. 